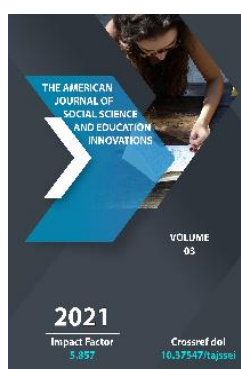

Copyright: Original content from this work may be used under the terms of the creative commons attributes 4.0 licence.

\section{Rhetoric As An Aspect Of The Functioning Of The Modern Russian Literary Language}

Shirin Shanigmatova

Teacher Of School Number 21, Ferghana, Uzbekistan

Timur Alimov

Lecturer At The Department Of Methodology Of Russian Language, Ferghana State

University, Ferghana, Uzbekistan

\title{
ABSTRACT
}

Nowadays, the importance of studying rhetoric is becoming more and more obvious, interest in it is growing: first, it is perceived as something completely new; secondly, the XXI century. - this is the time of democratic transformations in our country, this is the time of new people, unencumbered by censorship, who were given the opportunity to freely express their own opinion, to formulate their position in life. Modern man understands that the ability to speak largely determines his social status.

\section{KEYWORDS}

Rhetoric, neorhetoric, linguistics, literature, paths and figures of speech, art, communication.

\section{INTRODUCTION}

The objective of the research work is to present a linguistic analysis of rhetorical texts. Nevertheless, today we are forced to admit that modern domestic rhetoric, having survived a rather long period of stagnation, has significantly lagged behind the rhetoric of other civilized countries, that rhetoric abroad has made a huge step forward, directly linking itself with social and economic progress, and, therefore, with the professional training of each individual person. So, for example, at present, neorhetoric has become widespread. Neorhetoric is engaged in the search for the best options for public communication. This is the science of persuasive communication. It is being developed at the intersection of linguistics, theory of literature, logic, philosophy, ethics, aesthetics, psychology. 
Higher education is just beginning to get acquainted with modern communication technologies, in particular, with rhetorical art. The leading place in the social networks of young people is occupied by the use of neolexics. Stable phrases and special words were the result of the functioning and their use when communicating in the virtual world $[1, p$. 114].

The dynamism of the socio-political processes at the turn of the millennium, observed all over the world, suggests re-evaluating the ratio of written and oral forms of speech. The problem of written literacy should be solved in the conditions of not only secondary schools and academic lyceums, but also higher educational institutions. It is known that oral speech, which is extremely difficult to master, since it focuses not only on everyday communication, but also on other spheres of communication, primarily official, must be taught already from school and continued in higher education. However, public speech is still aloof from the state problems of education, especially in universities. The discipline "modern Russian language" involves the introduction of the discipline "Fundamentals of rhetorical art" into the curriculum and mastering the basics of rhetoric at the proper level.

\section{DISCUSSION}

Before talking about the meaning and role of rhetoric in modern society, we consider it important to refer to the definition of this concept. In this regard, let us clarify the definition of "rhetoric". The word "rhetoric" is of Greek origin (ip. Rheo - "to speak"). You can speak in different ways, hence the two meanings of the term rhetoric. Firstly, it is understood as "oratory", and secondly, as "pompous, unnecessarily beautiful speech."
The definitions of rhetoric include the following ideas:

1) Rhetoric is the fundamental theory and art of speech: the theory examines the laws and rules for constructing all types of speech in the modern information society, and art is understood as a certain skill, technical "skill", practical "dexterity" to own thoughts and words in different communication situations. This definition goes back to the classical definition of Golub's rhetoric: "The subject of rhetoric is speech" [2, p. 24].

2) Rhetoric is the art of thinking. Teaching speech in rhetoric has always involved the simultaneous learning to think (and think morally), form a worldview, gain knowledge and express one's position in life in words. Hence the special seriousness of rhetoric as a real thought-speech creativity, expressing the position of each person in life.

3) Rhetoric - the theory and practice of perfect speech: convincing, decorated, appropriate, effective, expedient, etc. All of these qualities can be questioned, since any "beautiful" or "convincing" speech can be turned, as they say, "into evil." Nevertheless, each era gives birth to its own rhetorical (communicative) ideal. Therefore, it is possible to say that rhetoric forms a lifestyle through the style of speech. In accordance with man's striving for the perfect Word, it is advisable to call rhetoric the doctrine of perfect speech.

4) Rhetoric - the doctrine of speech education of the individual. Since the whole person is expressed in speech, rhetoric contributes to the formation of the entire personality of a person, first of all - his ideology, knowledge, life position, the ability to 
express and defend his position in words. Compliance with this requirement makes it possible to educate such a person for whom the language (word, mouth) becomes a true "wall" and "fence", and the society in which he lives and works becomes prosperous due to properly organized speech connections.

5) Rhetoric - teaching about all kinds, types and genres of speech (literature) in a developed information society. It is wrong to limit rhetoric only to oratory (oratorical), modern rhetoric studies the whole variety of texts included in the culture: from everyday speech to the speech of the media. A developed linguistic personality should orientate and master different types of literature, understand their nature and have communication skills in the construction of texts. The task of philological science, which normalizes social speech practice, is the description and selection of cultural texts, i.e. those texts that are exemplary and can be included in education, providing a link between generations and effective creative activity of society.

In our opinion, there is no contradiction in these two meanings. In any case, the quality of speech, built according to the laws of rhetoric, remains high - the problem lies in the negative or positive consequences of the speeches delivered. This was understood by the ancient Greeks, who, together with the epic, lyrics, drama, sculpture, music and architecture, recognized rhetoric as necessary and complex creativity, moreover, it was considered the "queen of the arts" [3, p. 28]. It is no coincidence that three goddesses act as the patroness of rhetoric in Ancient Greece at once - Peyto - the goddess of persuasion, two Eris (good and evil) - goddesses of dispute; and history, philosophy and art are patronized only by the muse of Clio.

In our opinion, it is important here to make a small excursion into the history of this term. Rhetoric originated in the 5 th century $B C$, in Ancient Greece, in the era of Pericles, who ruled Athens for more than 15 years. Speaking with speeches, Pericles always took into account the mood and requests of the audience, carefully practiced his speeches and monitored the accuracy and expressiveness of their pronunciation. The Greeks distinguished between a "constructive" dispute, aimed at achieving the truth, and a conflict dispute, the purpose of which is not to clarify the truth, but to fight the enemy and victory in this struggle (agone, hence the Russian word agony - "fight against death").

This was an era when the Word was highly valued. V.G. Belinsky wrote: "The republican form of government made eloquence the most important and necessary art" [4, p. 68]. The founder of Attic eloquence, Gorgiy, noted: "The word is a great ruler, but small and imperceptible in body, it does divine deeds, because it is capable of stopping fear, and calming grief, and instilling joy, and pity to multiply" [5, p. 74]. Homer wrote about the orator in the following way: "By his outward appearance, he is not worthy of attention - by the beauty of speech, but he is gifted from the Gods; people rejoice, looking at him, speaking with firm courage or with affable meekness; he is the adornment of meetings; They see God in him when he walks through the streets of the city" [5, p. 59].

Historical necessity contributed to the flourishing of rhetoric: the fall of tyranny in Sicily led to the establishment of democratic 
forms of government. In Hellas, city-states with a developing slave-owning democracy were widespread. The supreme body in them was the National Assembly. Not only political issues were publicly resolved, but also a court was held. It was at this time that the profession of a logographer became especially popular - a person who writes speeches on request. The task of the logographer was to make the speech written by him sound natural in the mouth of the speaker, who had to defend his interests in court himself.

The same thought can be expressed in different ways. This largely depends on the tactics of speech impact. There is a direct tactic: the speaker, when making a speech, has in mind exactly as much as is laid down in the direct meaning of the linguistic means used by him. But in real life, more often guided by ethical considerations, we resort to indirect tactics (for example, saying a compliment, hinting at something, joking). In indirect tactics, the speaker uses tropes and figures of speech as a deviation from direct impact on the speaker.

In modern rhetoric, the terms are widely used tropes and figures of speech. Antiquity did not distinguish between these concepts. Modern educational literature treats trope as a word or expression in a figurative sense and refers to it, first of all, metaphor and metonymy, and sometimes - irony, paradox, hint - in a word, everything that is related to the tactics of indirect influence on the addressee.

It should be remembered that only those rhetorical means are essential for rhetoric that retain imagery, therefore the speaker should not resort to faded, dead paths, the use of which generates stereotyped, cliched speech. Naturally, not everyone is able to be the creators of figurative speech, however, for those who strive for this, Aristotle offered several recommendations: you cannot build a metaphor or comparison on the comparison of objects of the same class (for example, crucian carp like a pike); if you want to say something bad about an object, compare it with a household object, if good - with something unusual, unattainable. If we worship a person, call him the sun, treasure, wizard, nugget, goddess, if we estimate low, for example, the mental abilities of a person, we say: donkey, tree stump, cork, burdock, block.

Metaphor is very important to the speaker. It helps a person to feel like a creator, through a metaphor the speaker expresses his individuality, his special view of the world. Compare: "Just as clothing, first invented to protect against the cold, later began to be used also to decorate the body, and both the insignia and metaphorical expressions introduced due to a lack of words began to be used in many for the sake of delight" (Cicero). At the same time, it should be remembered that excessive metaphorical speech burdens the style.

If a metaphor is a transfer by the similarity of objects, then metonymy is a transfer by contiguity. The nominative functions of metonymy are expressed much more clearly than the figurative ones. That is why we sometimes do not feel the presence of metonymy (the kettle is boiling). This can be the name of an object by material (to clean the silverware), by property (my sun), by the manufacturer of the action (read Pushkin), etc. The image of metonymy is enhanced when we deal with its variety - synecdoche. For example, in the practice of speech, the speaker's desire to name a person by his clothes is found (Hey, hat, pass it ahead for two tickets). 
For the tactics of indirectly influencing the listener, a paraphrase, which is based on a descriptive expression, plays an important role. The subject is not called directly, but is characterized through the enumeration of its signs. ATS can be called a peaceful atom, St. Petersburg - the Venice of the North, oil - black gold, if they want to make a favorable impression of the subject. Environmentalists, on the other hand, can call ATC a potential Chernobyl in order to form a negative attitude towards the subject in the listener.

The trope includes an antiphrasis - the use of a word or expression that carries an assessment opposite to that which is evident from the context. Antifrasis has two varieties: irony - an overestimation in order to lower it and meiosis - an underestimation in order to increase it. We ironically call a weak person Hercules, an ugly one Apollo (irony), "Where are we going. gray and wretched, up to you. oligarchs "(meiosis). The ultimate, most harsh expression of irony is sarcasm.

The means of indirect influence on the listener also includes a hint. It involves "thinking out" the information conveyed by the speaker. This path must be used in order to avoid edifying in communication: sometimes it is enough for the interlocutor to hint so that he understands the erroneousness of his own position. From corporate considerations, it is necessary to help a person "save face". This allows for conflict-free communication [4].

The productivity of perception also depends on the elements of "recognizability" of the sounding text. This is where the elements of intertextuality come into play. For example, applique - "interspersed with well-known expressions (phraseological units, proverbs, sayings), but in a modified form." Wed: "They demanded to give Gorbachev 10 years without the right to correspond with Margaret Thatcher." Communication becomes lively, the author demonstrates wit. This technique has something in common with the so-called allusion - it is a hint at well-known historical or literary facts. Let's compare: "Man - it sounds bitter". The illusion revives memories, makes you think, the effect of recognition is triggered.

\section{CONCLUSION}

Thus, the subject of rhetoric is public speech. Determining the subject of rhetoric, one should answer the question: can it be considered an art, a gift that is given from above, or it is quite possible to teach beautiful speech? After all, the content of the rhetoric course depends on the solution of this issue (does it make sense to develop methodological recommendations to which the speaker should resort if you do not believe in their power?) that are driven by habit and those that act by chance.

If we approach rhetoric from the point of view of pragmatism, then it should be noted that the task of a modern specialist is not only to master the system of special, narrow professional knowledge, but also to learn how to exchange this knowledge, introduce it into life in the context of globalization, and conduct active negotiations with business partners, competently build their professional activities, relying on modern technologies of public communication, which determines the relevance of the study.

\section{REFERENCES}

1. Alimov T.E. Functioning of youth slang in mass media: International journal of integrated education Volume 4, Issue 2, 2021. 
2. Голуб И.Б. Русский язык и культура

речи. - Москва: Университетская книга «Логос», 2006.

3. Граудина П.К., Ширяев Е.Н. Культура русской речи. - Москва: Норма, 2006.

4. Далецкий Ч.Б. Риторика: заговори, и я скажу, кто ты. - Москва: Омега, 2004.

5. Ерохина Е.Л. Педагогическая риторика. - Москва: Олимп, 2004.

6. Казакова Т.Е. Основные понятия риторики как науки об эффективной речи. - Тюмень: ТюмГУ, 2010.

7. Farfieva K. A. Social Media as a factor in formation of scientific thinking in youth. European Journal of Research and Reflection in Educational Sciences. Vol. 8 No. 10, 2020. - Pp. 52-56.

8. Ismatullayeva, N. R. (2020). Probability Prediction Strategy In Simultaneous Interpretation. CURRENT RESEARCH JOURNAL OF PHILOLOGICAL SCIENCES, 1(01), 1-6. 